\title{
Habitat characterization and nutritional strategies of the endosymbiont-bearing bivalve Lucinoma aequizonata
}

\author{
S. C. Cary, R. D. Vetter, H. Felbeck \\ Marine Biology Research Divison, Scripps Institution of Oceanography, University of California, San Diego, La Jolla, \\ California 92093, USA
}

\begin{abstract}
A population of the lucinid bivalve Lucinoma aequizonata, with sulfur-oxidizing endosymbiotic bacteria in the gills, is restricted to a narrow depth range $(500 \pm 10 \mathrm{~m})$ on the slope of the Santa Barbara Basin, California, USA. In this zone, the seawater just above the substratum is sub-oxic $\left(\left[\mathrm{O}_{2}\right]\right.$ $<20 \mu \mathrm{M}$ ). The organically rich sediments in which these clams live are well mixed by bioturbation, which appears to maintain a redox condition limiting the extensive accumulation of hydrogen sulfide. However, thiol levels in the blood of the clams indicate an exposure to significant amounts of sulfide and/or thiosulfate apparently from randomly dispersed short-lived pockets of sulfidic mud that can be reached by the clam's burrowing vermiform foot. When the bivalves are incubated in the presence of hydrogen sulfide, thiosulfate is concentrated in the blood and apparently utilized by the bacteria for metabolic energy and the production of intracellular elemental sulfur. Laboratory growth experiments demonstrated that sulfide concentrations greater than $10 \mu \mathrm{M}$ were detrimental to the host, even though the bacteria continued to accumulate elemental sulfur. The utilization of thiosulfate under near anaerobic conditions and the accumulation of intracellular elemental sulfur by the endosymbiotic bacteria coupled with the high availability of environmental nitrate and low molecular oxygen suggests a metabolic strategy analogous to the free-living sulfur oxidizer Thiobacillus denitrificans. The $\delta^{13} \mathrm{C}$ values of the purified endosymbiont bacteria $(-34.0 \pm 0.8 \%$ ) were significantly lighter than those of the host tissue $(-29.0 \pm 0.7 \%$ suggesting that in addition to the nutrition provided by the bacteria, over $25 \%$ of the host carbon may be attributed to exogenous dissolved carbon which is in high concentrations in its natural habitat.
\end{abstract}

\section{INTRODUCTION}

Marine molluscs that contain symbiotic sulfur-oxidizing chemolithoautotrophic bacteria are known from a variety of sulfide-rich habitats, such as: sewage outfall areas (Felbeck et al. 1981), pulp mill effluent sites (Reid 1980), anoxic basins (Felbeck et al. 1981), brine and hydrocarbon seepage sites (Paull et al. 1984, Brooks et al. 1987), mangrove swamps (Schweimanns \& Felbeck 1985), seagrass beds (Fisher \& Hand 1984), and hydrothermal vents (Felbeck 1981, 1985, Cavanaugh 1983). A common feature of these habitats is the simultaneous availability of biogenically or geochemically produced hydrogen sulfide and molecular oxygen. Key enzymes for sulfur metabolism and carbon dioxide fixation via the Calvin-Benson cycle have been identified in the symbiont-containing tissues. Current theory holds that the bacteria provide the host with some form of chemosynthetically fixed carbon obtained through the oxidation of reduced sulfur, in return for a protected environment (Felbeck 1985, Anderson et al. 1987).

Sulfur-based symbioses in molluscs are not restricted to sulfide-rich habitats, but are found in sediment environments where sulfide concentrations are extremely low (Dando et al. 1985, Dando \& Southward 1986, Dando et al. 1986). Although enzyme analyses and the presence of accumulated elemental sulfur in the gills of such bivalves would indicate an active sulfur metabolism, it is uncertain by what mechanism enough sulfide is obtained to meet the metabolic demands of the host/symbiont system. The study of the nutritional interaction between host and symbiont has been hindered because these molluscs are difficult to maintain in the laboratory. Moreover in vitro cultivation of the symbionts has not been successful, and symbiont-free hosts are not as yet available. 
Several factors have identified the host's close nutritional dependency on its symbionts. The reduction or absence of a functional digestive tract in many of these symbiont-containing species (Alien 1958, Reid 1980) limits the hosts' nutritional sources to dissolved material and/or the translocation of reduced carbon from the symbionts. In addition, indirect evidence suggesting the importance of bacterial carbon in the hosts' nutrition comes from studies of stable carbon isotope ratios (Rau \& Hedges 1979, Rau 1981, Felbeck 1983). The isotopic composition of organic matter is determined by several well-characterized reactions which establish an isotopic signature that varies only slightly as the carbon moves through the trophic pathways (Rau et al. 1983, Fry \& Sherr 1984, Spiro et al. 1986). Such stability allows the origin and contribution of a carbon source in a particular organism to be estimated. The stable carbon isotope values reported in bivalves for tissues either with or without chemoautotrophic symbionts $\left({ }^{13} \mathrm{C}=-30\right.$ to $-28 \%$ ) are similar to each other and isotopically lighter (depleted in ${ }^{13} \mathrm{C}$ ) than analogous heterotrophic representatives (Rau 1981, 1985, Southward et al. 1981, Felbeck 1983, Spiro et al. 1986). The similarity of the 2 tissues qualitatively indicates that most of the nutritional requirements of the hosts are provided by the chemoautotrophic endosymbionts. If a difference in the $\delta^{13} \mathrm{C}$ values had been observed between these 2 tissues, it might represent the influence and importance of alternate sources of reduced carbon with different isotopic signatures (Fry \& Sherr 1984).

Most of the stable carbon isotope studies have used 'symbiont-containing' tissues, e.g. gill tissue, which were compared directly with host tissue. Since the great bulk of the symbiont-containing tissue is of host origin (95 to $98 \%$ ), the reported results may not have reflected the true isotopic variation between the host and bacteria. Therefore, the possible nutritional influence of alternative carbon sources may be masked because differences in the $\delta^{13} \mathrm{C}$ values would not have been detected. Previous isotopic studies have generally focused on species from sulfide-rich habitats where reduced sulfur substrates for the symbiosis are plentiful and there is less need to acquire reduced carbon from exogenous sources. In contrast, in symbiont-containing species that inhabit environments where reduced sulfur is both limited and its availability unpredictable, alternative sources of carbon could well play a more important role in the nutrition of the host.

In the present study we have investigated the nutritional strategy of a burrowing bivalve, Lucinoma aequizonata, that contains sulfur-oxidizing bacteria yet inhabits an almost sulfide-free environment. $L$. aequizonata inhabits the narrow anoxic/oxic boundary $(500 \pm 10 \mathrm{~m}$ depth) of the Santa Barbara Basin. The basin is essentially anoxic $\left(\left[\mathrm{O}_{2}\right]<10 \mu \mathrm{M}\right) 50 \mathrm{~m}$ below sill depth $(475 \mathrm{~m})$ except during periods of flushing (Sholkovitz \& Gieskes 1971). L. aequizonata, like other members of the family Lucinidae, contains endosymbionts in the gills and enzymes that identify sulfurbased metabolism with carbon fixation via the CalvinBenson cycle (Felbeck 1981, Schweimanns \& Felbeck 1985). The accumulation of elemental sulfur by the bacteria in the gills indicates reduced sulfur is available to the bivalves (Vetter 1985); however, no sulfide has been detected in the sediment pore water at this depth in the basin (present study). Dando et al. $(1985,1986)$ have investigated similar symbiotic bivalves that inhabit low sulfide environments yet have only speculated on the origin and importance of reduced sulfur compounds to the nutrition of these organisms

The purpose of this present investigation was to measure the nutritional resources in the sediment environment of Lucinoma aequizonata and to quantify the possible nutritional dependency of the host on its bacterial symbionts. Special attention is given to (1) geochemical characterization of the sediment/pore water habitat of $L$. aequizonata, (2) determination of how the clams obtain and manipulate reduced sulfur species, and (3) alternative carbon sources available to the bivalves.

\section{METHODS AND MATERIALS}

Collection of bivalves and symbiotic bacteria. A population of Lucinoma aequizonata appears to be restricted to the anoxic/oxic boundary on the slope of the Santa Barbara Basin, California, USA, at a depth of 490 to $510 \mathrm{~m}$ (Fig. 1). This zone is characterized by low oxygen levels, yet the sediment remains heavily bioturbated in comparison to the highly layered ('varved') sediments slightly deeper in the basin. Specimens for these studies were collected using either an Otter Trawl, or a Van Veen grab if the associated sediment was required. When necessary, animals were maintained in the laboratory in the sediments in which they were collected and at temperatures typical of their habitat $\left(7^{\circ} \mathrm{C}\right)$. Once on the surface, clams selected for samples of mantle water and blood analyses were immediately placed under a nitrogen atmosphere to inhibit the oxidation of reduced sulfur compounds that might be present. If the clam was acquired with the Van Veen grab, mud closely associated with it was collected for pore water thiol analyses

Clam mantle water was extracted by inserting a blunt spatula between the valves near the umbo and allowing the mantle water to drain. The clam was then carefully opened and the interior blotted dry. The blood was collected by making a shallow $(1 \mathrm{~mm})$ cut in the 


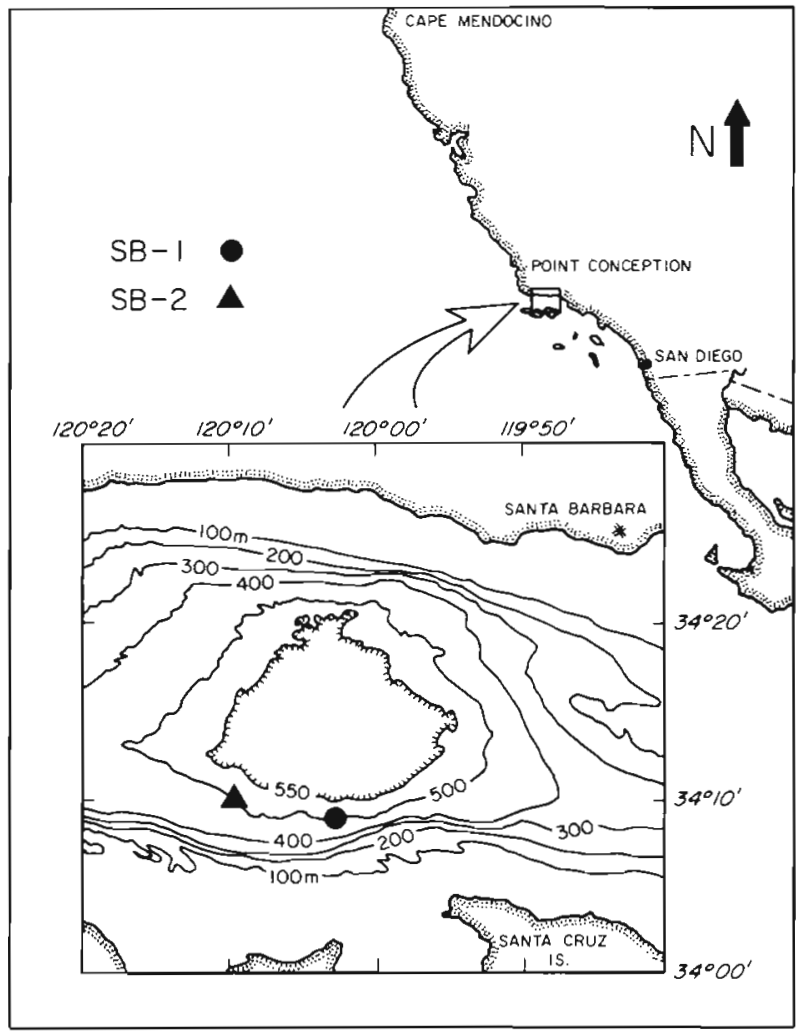

Fig. 1. Location of box cores SB-1 and SB-2 collected from the $500 \mathrm{~m}$ contour in the Santa Barbara Basin, California, USA

mantle with a scalpel and collecting the seeping fluid. The condition of the clams that were collected varied. Those with yellow gills, due to the presence of elemental sulfur (Vetter 1985), were considered in good health and those with black, atrophied gills, with few symbionts, were considered to be in poor condition. Symbiont (gill) and non-symbiont containing tissue (foot. mantle) samples were removed and frozen for stable isotopic analyses. In addition, purified bacteria were obtained from selected individuals by gradient centrifugation (Distel \& Felbeck 1988) and stored frozen for isotopic analyses. A filter-feeding bivalve mollusc Cyclocardia ventricosa and a small carnivorous gas. tropod Mitrella permodestra, which are predominant in this specialized habitat, were also collected and frozen for isotopic analyses.

Sediment pore water analyses. Sediments for pore water extractions were obtained from $500 \mathrm{~m}$ depth using a Soutar box core which is specifically designed to obtain sediments with an undisturbed surface (Soutar \& Crill 1977). Sub-cores (30 to $50 \mathrm{~cm}$ in length) were carefully taken in polyethylene core liners from 2 selected box cores, and stored capped in a refrigerator $\left(2^{\circ} \mathrm{C}\right)$ until they could be sub-sampled. On one occasion a healthy Lucinoma aequizonata was collected in the box core. A sub-core was taken near to the burrow, and the sediment and pore waters analysed.

All sediment processing was carried out in a glove bag under a nitrogen atmosphere at near in situ temperature $\left(7^{\circ} \mathrm{C}\right)$. The sub-cores were extruded at $0.5 \mathrm{~cm}$ increments for the first $2 \mathrm{~cm}$, and then at $1 \mathrm{~cm}$ increments to the bottom of the respective core. Each interval of sediment was sealed under nitrogen in a clean polyethylene tube and centrifuged at $2500 \times g$ for $5 \mathrm{~min}$. The tubes were returned to the glove bag, and the supernatant was removed by plastic syringe. The pore water was slowly filtered through a nucleopore filter $(0.22 \mu \mathrm{m})$ into acid-washed polyethylene vials. A part of each sample was acidified with ultraclean hydrochloric acid to $\mathrm{pH} 2$ for analysis of nitrate, iron, and manganese. An aliquot was removed immediately after filtering from the unacidified fraction for sulfide determination and a portion was frozen at $-80^{\circ} \mathrm{C}$ for amino acid analysis. Portions of the unacidified fraction were also analysed on board ship for ammonia and later in the laboratory for sulfate. The sediment pellets were sealed under a nitrogen atmosphere and frozen $\left(-80^{\circ} \mathrm{C}\right)$ for analysis of the remaining solids. A subsample of sediment from each depth section of the core was dried to constant weight at $100^{\circ} \mathrm{C}$ for determination of water content.

In addition to the sub-cores that were analysed, isolated mud samples based on color (black to green) were also taken from the Van Veen grab samples and independently analysed for reduced sulfur compounds. When a clam was collected in the grab, portions of the sediment surrounding the bivalve were sampled, acidtreated to remove bicarbonate, and then freeze-dried for organic carbon stable isotope analysis.

Determination of selected inorganic and organic components in pore water, mantle water and blood. Pore water concentrations of nitrate with nitrite (Gieskes \& Peretsman 1986), reduced iron (Stookey 1970), manganese (Brewer \& Spencer 1971), sulfate (Tabatabai 1974), and ammonia (Solorzano 1969) were determined by methods described by the respective authors. Amino acids in the pore water samples were derivatized with $o$-phthaldialdehyde (OPA) as described by Lindroth \& Mopper (1979). The OPAderivatives were separated by high pressure liquid chromatography (HPLC) using elution gradients as described by Manahan et al. (1983). Peaks were monitored fluorometrically and identified by elution time. Sixteen amino acids were quantified by digital integration with a maximum error of $\pm 4 \%$.

The concentrations of sulfide and thiosulfate were determined in blood, mantle water, and pore water by derivatization followed by HPLC (Vetter et al. 1987, Vetter et al. 1989), which is a modification of the original technique of Fahey \& Newton (1987). Samples were 
derivatized with monobromobimane on board ship and stored frozen. In the laboratory, the derivatized samples were separated by HPLC on a C-18 reverse-phase column with a methanol-water gradient and detected and quantified by fluorescence.

Sediment solid analyses. The solids from selected cores were analysed for bound thiols (metal sulfides) and carbon content. The percentage of acid-volatile sulfide (AVS) was determined gravimetrically by acidifying a portion of the sediment and precipitating any volatile sulfide in a silver nitrate trap (Klug et al. 1985). The remaining washed sediment was subjected to aqua regia oxidation for $16 \mathrm{~h}$ and the filtrate analysed for sulfate to determine the percentage of pyrite (Klug et al. 1985). The remainder of the sample was washed in deionized water and dried to constant weight at $100^{\circ} \mathrm{C}$. The organic carbon content of each of the fractions was determined using a Coulometer (Coulometrics Inc.) which measures carbon dioxide. Briefly, a known weight of the sample was combusted and the total carbon determined by the amount of carbon dioxide emitted. A second portion of the sample was acidified in $2 \mathrm{~N}$ hydrochloric acid and the percentage of carbonate was calculated from the liberated $\mathrm{CO}_{2}$. The percentage of organic carbon in salt-free dry sediments was then determined by difference.

Selected sediment samples from the cores were washed through a stack of 4 sieves $(250,177,125$, and $62 \mu \mathrm{m}$ mesh) and the fractions briefly washed in $3 \%$ hydrogen peroxide to disrupt the fecal pellets. The remaining foraminifera tests were combined, dried and weighed in order to determine the abundance and depth distribution of benthic and planktonic foraminifera.

Stable isotope analyses. Aliquots of the frozen tissues and isolated bacteria were later freeze-dried and prepared for stable carbon isotope determination. Portions of the dried tissues and sediments $(3 \pm 2 \mathrm{mg})$ were combusted at $850^{\circ} \mathrm{C}$ for $3 \mathrm{~h}$ in evacuated, sealed quartz ampules in the presence of copper, copper(II) oxide and silver as described by Stump \& Frazer (1973) and Northfelt et al. (1981). Carbon dioxide was purified, measured volumetrically, and sealed in pyrex tubes for subsequent mass-spectrometric analysis of the stable isotope ratios. All carbon isotopic results are expressed relative to Pee Dee Belemnite standards with a precision of $\pm 0.1 \%$.

Dissolved oxygen determination. In addition to the sediment core samples taken as described above, larger sub-cores were taken from the Soutar box core to be used as artificial burrow habitats. Three plexiglass core liners ( $15 \mathrm{~cm}$ diameter) were inserted into the sediment in the box core. The sealed liners were removed with the sediment sample and transferred into a glove bag that contained a gas mixture with a partial pressure of oxygen that would maintain an oxygen concentration in the chambers approximating the ambient environment $(20 \mu \mathrm{m})$. The artificial habitats were refrigerated to ambient temperature $\left(7^{\circ} \mathrm{C}\right)$ for the duration of the study. Care was taken not to disturb the finely graded surface sediments. In the laboratory, a peristaltic pump continually moved water from a central sump across the surface of each habitat within the glove bag. The sump water was replaced each day with fresh seawater degassed with the gas mixture. A single Lucinoma aequizonata was placed into each of the habitats and allowed to burrow for $2 \mathrm{wk}$.

Small-scale oxygen profiles were determined for the burrows with cathode-type oxygen microelectrodes and a separate reference electrode (Revsbech et al. 1980, Revsbech \& Ward 1983). The electrode potential was measured using a pico-ammeter in combination with a chart recorder. The electrodes were calibrated to the overlying water which was sampled prior to each profile and analysed using standard techniques (Strickland \& Parsons 1972). A micromanipulator allowed measurements to be taken in vertical steps of $500 \mu \mathrm{m} \pm$ $10 \mu \mathrm{m}$. Eight individual profiles were made on each of 3 established burrows in order to construct a 2-dimensional map of $\mathrm{O}_{2}$ distribution based on oxygen isopleths.

While at sea the oxygen profile of a fresh sub-core, which was taken directly from the box core, was obtained using the oxygen micro-electrodes. In addition, a Niskin bottle was attached to the Soutar Box Core, triggered to take a water sample ca $1 \mathrm{~m}$ above the sediment as the corer impacted with the mud. The dissolved oxygen of the water sample was determined using a modified colorimetric micro-WinkJer technique described by Broenkow \& Cline (1969).

Laboratory experimentation. Adult Lucinoma aequizonata were exposed to elevated concentrations of hydrogen sulfide for $8 \mathrm{wk}$. The effect on the host organism was determined by monitoring a relatively dynamic physiological parameter (e.g. the adenylate pool) and a less responsive parameter (e.g. the glycogen reserve). In addition, the growth rates of selected individuals were monitored using a highly accurate laser diffraction measuring device (Stromgren \& Cary 1984). The effects of sulfide on the symbionts was determined by monitoring the elemental sulfur content of the gills, which is thought to be an index of bacterial condition (Vetter 1985).

Four aquaria were set up with a constant flow of chilled seawater $\left(7^{\circ} \mathrm{C}\right)$, partially stripped of oxygen to simulate natural conditions $(20 \mu M)$. Concentrated sodium sulfide was pumped into the intake line of each aquarium such that the resulting sulfide concentrations were maintained at 10,30 or $50 \mu \mathrm{M}$. Distilled water was used in place of sodium sulfide for the zero sulfide 
control. The sulfide concentration in each aquarium was monitored daily by a colorimetric technique (Cline 1969). Oxygen was measured with a sulfide-insensitive polarographic oxygen electrode (Revsbech \& Ward 1983).

The clams were allowed to acclimate for $1 \mathrm{wk}$ in a holding tank with no sulfide source. Fifty mediumsized individuals $(1.5$ to $2 \mathrm{~cm})$ were placed in each aquarium; half of the specimens were mounted on plexiglass platforms for growth rate measurements, and half were held on a rack off the bottom to be used for the biochemical analyses.

Five clams were removed from each treatment every $7 \mathrm{~d}$ for the $5 \mathrm{wk}$ duration of the study. These specimens were dissected, and the tissue was frozen immediately in liquid nitrogen to ensure the stability of the adenylates. The tissue samples were stored at $-80^{\circ} \mathrm{C}$ until the end of the experiment. Clams held on the plexiglass platforms were removed from the tank weekly and measured. They were not held out of water for longer than 5 min during the measuring procedure.

Methods for the extraction and analyses of adenylates are described in detail in Vetter \& Hodson (1982). ATP measurements were made directly from the extract: the luciferin-luciferase reaction emitted light in proportion to the ATP concentration. ADP and AMP were enzymatically converted to ATP and quantified by difference. Enzyme conversions were corrected by using separate standard curves and regression equations for each of the 3 adenylates. The bioluminescence was measured on an LKB Luminometer 1250 interfaced to a digital integrator. Glycogen content of the tissue was determined on the same extract by an enzymatic technique described by Keppler \& Decker (1983). Where appropriate, the data were examined via 2-way analyses of variance $(2 \times$ ANOVA) and pair-wise comparisons of means by Student-Newman-Keuls ( $a=$ $0.05)$.

Elemental sulfur is insoluble and precipitates during the adenylate extraction procedure. The elemental sulfur content of the remaining pellets was determined by benzene extraction (Vetter 1985). The pellets were freeze-dried and extracted twice in benzene for $24 \mathrm{~h}$. The resulting supernatants were combined, evaporated to dryness under nitrogen and redissolved in a known volume of benzene. Aliquots of the extract were spotted onto strips of filter paper and assayed spectrophotometrically according to Schedel \& Trüper (1980).

In addition, during the course of this study, yellowand black-gilled clams ( 5 each) were incubated either in the presence of no sulfide or in the presence of $30 \mu \mathrm{M}$ sulfide for $3 \mathrm{wk}$. At the end of this period, the clams were removed and assayed for blood sulfide and thiosulfate concentrations as previously described.

\section{RESULTS}

\section{Sediment chemistry}

The Santa Barbara basin is a high depositional environment due to highly productive surface waters and a close proximity to terrestrial run off (Hülsemann \& Emery 1961). The sediment is of fine-grain hemipelagic consistency and, even with the high organic input, no varving or layering was observed in any of the cores taken from the $500 \mathrm{~m}$ contour.

The analyses of metals in pore water can be used to establish depth profiles that define redox conditions and diagenetic reactions occurring in the sediments. Although there was some variability in the pore water chemistry between various sites in the Santa Barbara Basin at $500 \mathrm{~m}$ the geochemical trends are best represented in the sediment taken from the box core in which a healthy clam was recovered (SB-1) and a shallower core (SB-2) from the southwestern side of the basin (Fig. 1). Geochemical analyses of pore water were carried out on SB-1 and the organic and thiol measurements conducted on SB- 2 .

Average sediment temperature in the box cores was $7.2^{\circ} \mathrm{C}$, and the water content of the sediment ranged from 74 to $64 \%$ by weight. The oxygen concentration ca $1 \mathrm{~m}$ above the sediment-water interface was extremely depleted (18 to $20 \mu M$ ). Typically, in a reducing habitat, when all oxygen has been consumed by the oxidation of organic matter, the redox potential is driven low enough to favor the next most efficient oxidant. In the cores taken from the Santa Barbara Basin at $500 \mathrm{~m}$, oxygen disappeared from the pore waters in the first few millimeters of the core.

Nitrate was present at low concentrations throughout the cores indicating significant nitrate reduction (denitrification). This early nitrate depletion was closely followed by a mobilization of dissolved manganese $\left(\mathrm{Mn}^{2+}\right)$ and, slightly deeper in the core, by dissolved iron $\left(\mathrm{Fe}^{2+}\right)$, both originating from high concentrations of solid phase manganese and iron oxides in the sediments (Fig. 2). In classical redox sequences, when solid phase manganese and iron are depleted, the dissolved iron and manganese profiles are intersected by the reduction of sulfate, the oxidant producing the next most energy. However, in this sediment, elevated iron and manganese profiles persist throughout most of the core without any indication of sulfate reduction. In the deeper core (SB-1), at $17 \mathrm{~cm}$ depth, a depletion of iron corresponded to an enrichment in ammonia (Fig. 2). In reducing environments, ammonia enrichment would normally indicate the occurrence of significant sulfate reduction (Froelich et al. 1979); however, in these sections, sulfate concentrations remained relatively constant throughout the cores. Sulfide and thiosulfate 


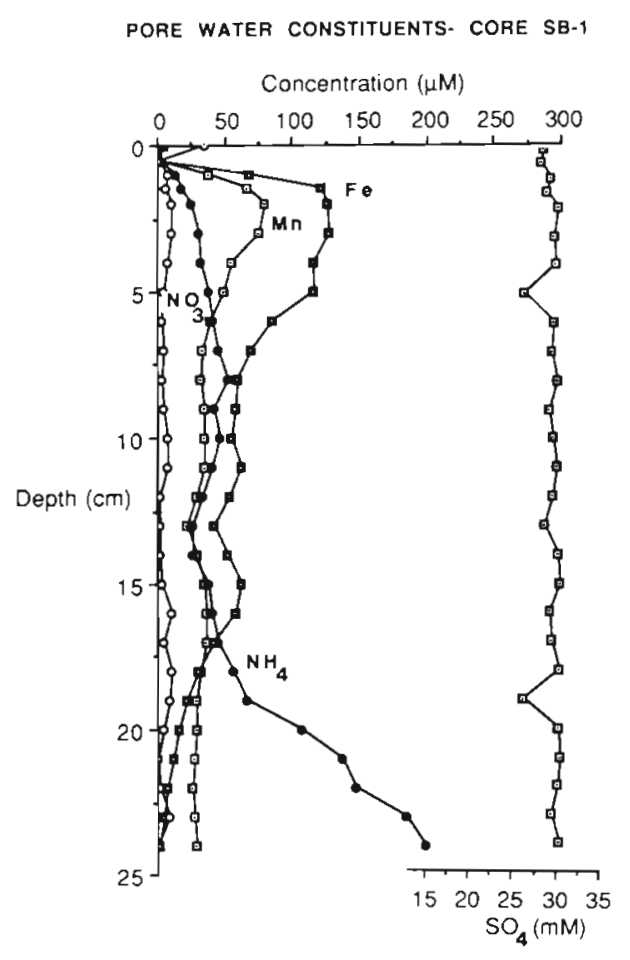

Fig. 2. Pore water constituents from sub-core SB-1

occur at detectable concentrations $(>200 \mathrm{nM}$ ) only in isolated sections of the cores sampled as illustrated in Fig. 3A (Core SB-2).

When sampled separately, pockets of black mud had elevated sulfide levels $(21.7 \pm 2.41 \mu M, n=8)$ and were often associated with high densities of fecal pellets and benthic foraminifera, predominantly Bolivina argentea and Globobulimina pacifica (Fig. 3B). The pelagic foraminifera component in the sediment rarely exceeded $0.5 \%$ of the sediment dry weight. If compared with other cores taken at a similar depth in the basin, these sulfide anomalies appeared isolated and randomly dispersed.

The organic carbon content of the sediment from the shallower core (SBS-2) ranged from 3.1 to $4.7 \%$ (dry weight), decreasing slightly with depth (Fig. 3C). The acid-volatile sulfide concentration was generally low throughout this core, never exceeding 4 umol $\mathrm{g}^{-1}$ dry weight of sediment. Pyrite levels remained constant (5 $\mu \mathrm{mol} \mathrm{g}^{-1}$ dry weight) to $11 \mathrm{~cm}$ depth then progressively increased 4 -fold to $20 \mu \mathrm{mol} \mathrm{g}{ }^{-1}$ dry weight at the bottom of the core (Fig. 3D).

Total amino acid concentration in the pore water of Core SB-2 gradually increased with depth from $4.8 \mu \mathrm{M}$ at the sediment-water interface to $90 \mu M$ in the $15 \mathrm{~cm}$ section (Fig. 4). Concentrations exceeded $200 \mu M$ in only one section $(6 \mathrm{~cm})$ which corresponded to elevated sulfide, thiosulfate, pyrite and an increase in foramini- fera abundance. Pore water amino acid composition was dominated by alanine, glycine, and glutamate.

\section{Stable carbon isotope composition}

The stable carbon isotope values for Lucinoma aequizonata host tissue were depleted in ${ }^{13} \mathrm{C}\left(\delta{ }^{13} \mathrm{C}=\right.$ $-29.0 \pm 0.7 \%, n=10$ ) and comparable to those reported for other bivalves that contain chemoautotrophic symbionts (Fig. 5). The purified bacterial fractions from the symbiont-containnig gills showed even lighter carbon values at $-34.0 \pm 0.8 \%(n=5)$. The

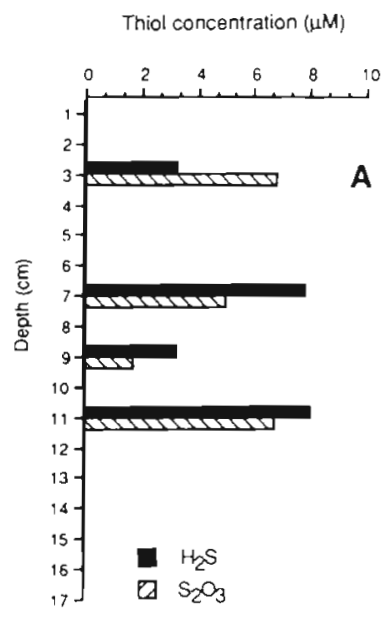

Foraminiferal abundance (\% dry we sed)

Weight percent in salt-free dry sediment
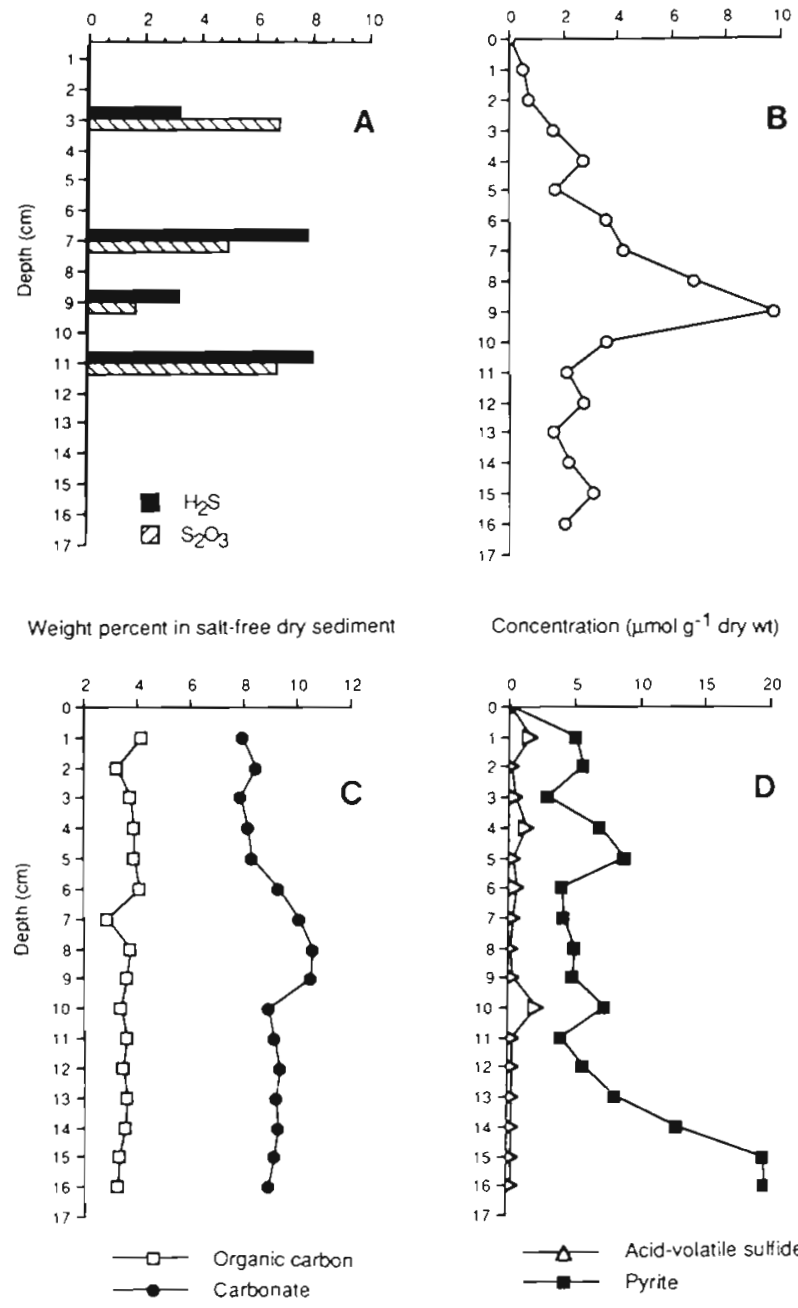

Concentration ( $\left.\mu \mathrm{mol} \mathrm{g}^{-1} \mathrm{dry} w \mathrm{wt}\right)$

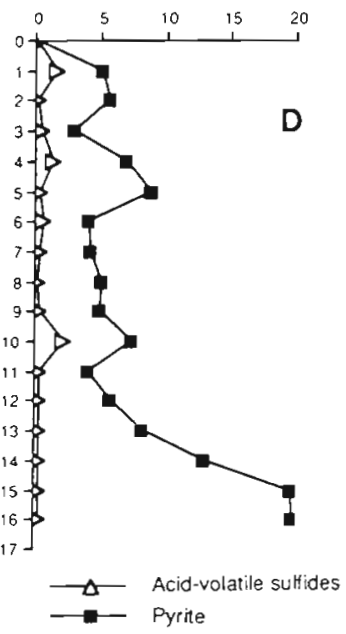

Fig. 3. Pore water thiols and remaining solids composition from subcore SB-2. (A) Pore water sulfide and thiosulfate concentrations taken at $1 \mathrm{~cm}$ depth intervals. (Depths with no bars are zero values.) (B) Infaunal foraminifera abundance expressed as a percentage of the dry weight of the sediment. (C) Organic carbon and carbonate expressed as a percentage of salt-free dry sediment. (D) Concentration of metal bound sulfides: AVS and pyrite 
Fig. 4. Concentration and composition of dissolved free amino acids (DFAA) in the pore waters of sub-core SB-1 taken from $500 \mathrm{~m}$ in the Santa Barbara Basin. Sixteen amino acids were differentiated; the 5 amino acids in highest concentrations are expressed individually and the remainder as a group (others). Concentration of DFAA in the $6 \mathrm{~cm}$ section (arrow) exceeded $200 \mu \mathrm{M}$

non-symbiont bearing bivalve $(-20.6 \% \pm 0.2, n=3)$ and the carnivorous gastropod $(-16.2 \%, n=1)$ had values similar to the sediment carbon $(-21.6 \% \pm 0.1$, $n=3$ ). This suggests they obtain their carbon directly or indirectly from photosynthetically derived plant material (Fry \& Sherr 1984).

\section{Thiol concentrations in blood and mantle water}

Analysis of the blood and mantle water can provide insight into the levels of reduced sulfur compounds experienced by Lucinoma aequizonata in its natural habitat and may indicate how the reduced sulfur compounds are later manipulated by host and symbiont. The blood chemistry of clams collected by Van Veen grab and the Otter Trawl were not significantly different and so were treated as one group.

The concentration of free sulfide in the blood of the naturally occurring yellow-gilled clams $(9.51 \pm 2.7 \mu \mathrm{M}$, $n=23$ ) was not significantly different than that of clams with black gills $(8.89 \pm 4.6 \mu M, n=14)$, however, in both cases, the blood sulfide was elevated over the sulfide concentration in the mantle water (Table 1). The thiosulfate levels in the blood $(62.13 \pm 21.7 \mu M, n=23)$ and mantle water $(77.83 \pm 13.8 \mu M, n=23)$ of these yellow-gilled clams were an order of magnitude higher than the associated sulfide concentration. In addition, these thiosulfate levels were considerably higher than any of the thiols in the blood or mantle water of the black-gilled clams (Table 1).

Clams with yellow gills that were held in an aquarium free of sulfide for $3 \mathrm{wk}$ had significantlv lower blood thiosulfate concentrations than naturally occurring clams with a similar gill color (Table 1). In addition, there was a noticeable fading of the yellow coloration during the period of the incubation, presum-

- 'Thiol' is used in a broad sense to include those reduced sulfur compounds derivatized by the thiol reagent, monobromobimane (Fahey \& Newton 1987). It includes sulfide, thiosulfate and sulfite as well as true sulfhydryl compounds
Dissolved tree amıno acid concentration $(\mu \mathrm{M})$

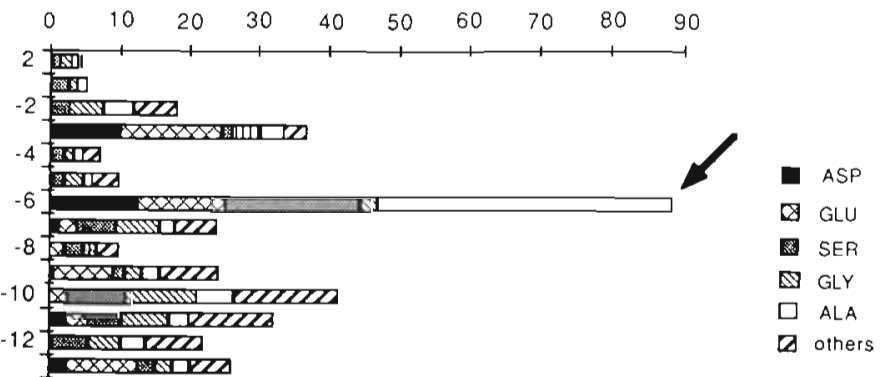

ably because elemental sulfur stores were utilized by the bacteria. The blood thiol concentrations of the black-gilled clams held free of sulfide remained unchanged. Yellow-gilled specimens, maintained in an aquarium which was continuously supplied with sulfide $(30 \mu M)$, showed the highest levels of thiosulfate $(1.7 \mu M)$ and had blood sulfide concentrations that matched the external sulfide levels in the treatment. The black-gilled clams, held under the same conditions, had both sulfide and thiosulfate concentrations which were elevated but not to the extent of the yellow-gilled clams.

\section{Physiological studies}

Due to the opaqueness of the shell it was impossible to determine gill color prior to the incubation experiments. This resulted in a high initial variability in the adenylate pool and in glycogen stores. This variability

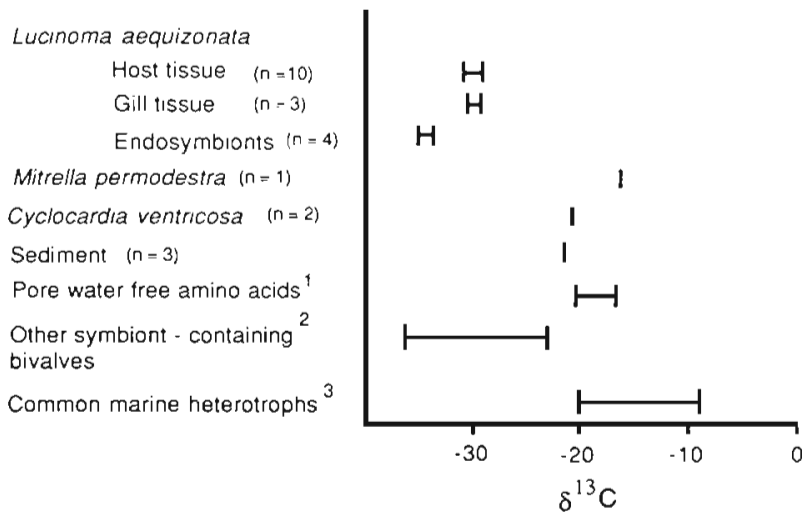

Fig. 5. Lucinoma aequizonata, Mitrella permodestra, and an unidentified bivalve. Comparison of stable carbon isotope values $\left({ }^{13} \mathrm{C} /{ }^{12} \mathrm{C}\right)$ of tissues from $L$. aequizonata and 2 nonsymbiont containing molluscs from the $500 \mathrm{~m}$ contour of the Santa Barbara Basin with those of the local sediment and other marine heterotrophic organisms. Bars indicate range of values for each category. $\mathrm{n}$ : number of individuals analysed. $\left({ }^{1}\right.$ Degens 1969; ${ }^{2}$ Rau \& Hedges 1979, Rau 1981, 1985, Spiro et al. $1986 ;{ }^{3}$ Fry \& Sherr 1984, Gearing et al. 1984) 
Table 1. Lucinoma aequizonata. Blood and mantle water thiol concentrations of yellow-and black-gilled clams taken directy from the natural environment and held in the laboratory with and without sulfide. Mean values ( \pm SD) are given for each of the conditions. $n$ : number of individuals sampled

\begin{tabular}{|c|c|c|c|c|c|}
\hline \multicolumn{6}{|c|}{ Blood and mantle water thiol concentrations } \\
\hline Source & Gill color & Sample & Sulfide $(\mu M)$ & Thiosulfate $(\mu \mathrm{M})$ & $n$ \\
\hline \multirow{4}{*}{$\begin{array}{l}\text { Natural } \\
\text { condition }\end{array}$} & Yellow & Blood & $9.5 \pm 2.7$ & $126.9 \pm 61.7$ & 23 \\
\hline & Yellow & Mantle water & $5.3 \pm 4.1$ & $108.8 \pm 63.8$ & 23 \\
\hline & Black & Blood & $8.9 \pm 4.6$ & $11.9 \pm 7.3$ & 14 \\
\hline & Black & Mantle water & $2.8 \pm 2.2$ & $5.4 \pm 4.6$ & 13 \\
\hline \multirow{2}{*}{$\begin{array}{l}\text { Aquarium } \\
\text { (no sulfide) }\end{array}$} & Yellow & Blood & $6.7 \pm 2.9$ & $18.0 \pm 5.2$ & 6 \\
\hline & Black & Blood & $4.6 \pm 3.8$ & $5.9 \pm 3.5$ & 6 \\
\hline \multirow{2}{*}{$\begin{array}{l}\text { Aquarium } \\
\text { (30 } \mathrm{M} \text { sulfide) }\end{array}$} & Yellow & Blood & $27.7 \pm 7.6$ & $1709 \pm 413$ & 5 \\
\hline & Black & Blood & $22.4 \pm 4.7$ & $732.4 \pm 241$ & 5 \\
\hline
\end{tabular}

was retained throughout the experiment, resulting in no significant difference between clams held under any of the 4 sulfide concentrations. The high degree of individual variability in glycogen stores and energy charge hinders our interpretations of the results. Growth and elemental sulfur content provided clues to assess the physiological conditions of the clam and symbionts in response to the presence of sulfide. An initial lag period of $1 \mathrm{wk}$ was observed before any stimulation of growth was detected (Fig. 6). Maximum growth rates $\left(12.1 \pm 2.2 \mu \mathrm{m} \mathrm{d}^{-1}\right)$ were achieved after $4 \mathrm{wk}$ at the lowest sulfide concentration. Under each of the higher sulfide concentrations that the clams were exposed to, the growth rates decreased. The growth rates of clams held in $50 \mu \mathrm{M}$ sulfide were lowest and not significantly different from those held without sulfide.

The production and accumulation of elemental sulfur has not been detected or observed in eukaryotes and is believed to be exclusively a prokaryotic trait. A change in elemental sulfur content would, therefore, indicate a metabolic response by the bacterial endosymbionts to the external conditions provided. The elemental sulfur content of clams held without sulfide decreased to undetectable levels in only $3 \mathrm{wk}$ (Fig, 6). Although clams incubated at the highest sulfide concentrations accumulated the most elemental sulfur ( 8 to $11 \%$ ) they also suffered the highest mortality $(62 \%)$. Clams incubated at $10 \mu \mathrm{M}$ sulfide had no mortality throughout the course of the experiment and had elemental sulfur levels similar to those of naturally occurring Lucinoma aequizonata ( 4 to $6 \%$ )

\section{Artificial habitat experiment}

In the artificial habitat experiments the clams constructed and remained in shallow burrows about 2 to $5 \mathrm{~cm}$ in depth for extended periods of time. The clams normally established both inhalant and exhalant siphons to the sediment surface in several days. Microelectrode oxygen measurements of the artificial habitats in the laboratory corresponded to those of the sub-cores sampled on the ship. The sediment showed no oxygen several millimeters below the sediment surface. The overlying water oxygen concentrations averaged $20 \mu \mathrm{M}$. The clams maintained the burrow oxygen level higher than that of the surrounding sediment but considerably lower than in the overlying water (Fig. 7).
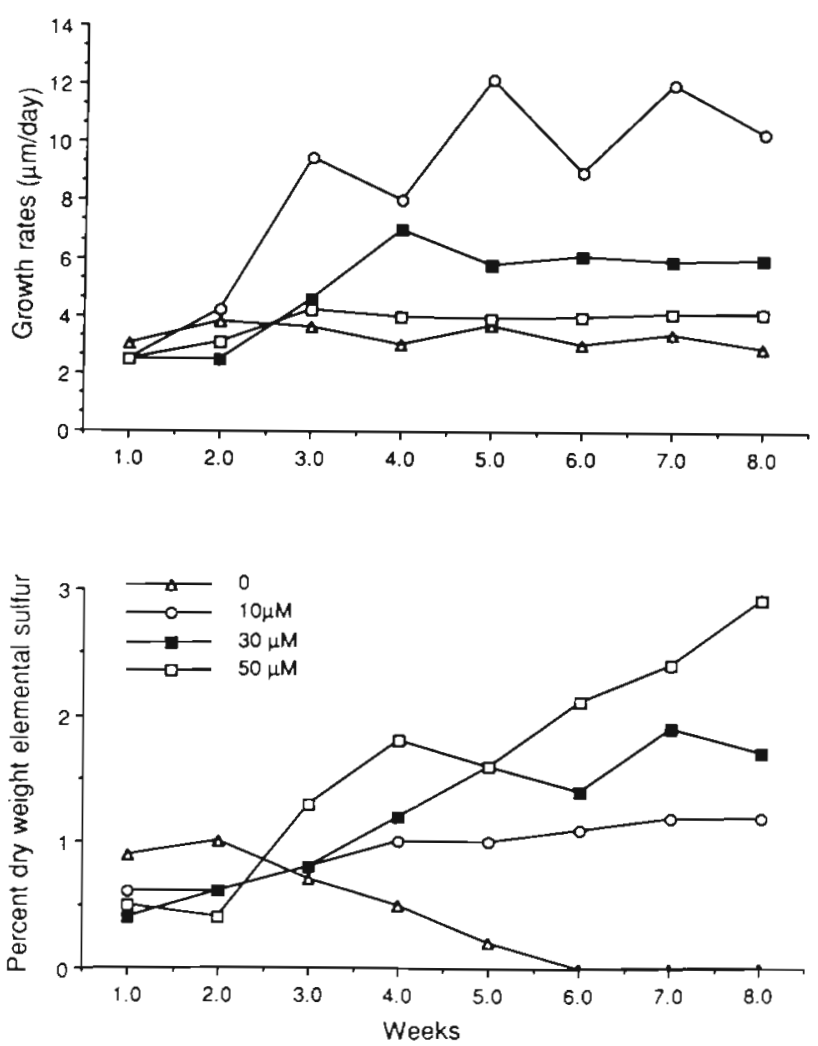

Fig. 6. Lucinoma aequizonata. Growth rates and elemental sulfur content of clams exposed to varying levels of hydrogen sulfide. Standard deviations never exceeded $\pm 2 \mu \mathrm{m} \mathrm{d} \mathrm{d}^{-1}$ and $\pm 0.5 \%$ elemental sulfur, respectively 


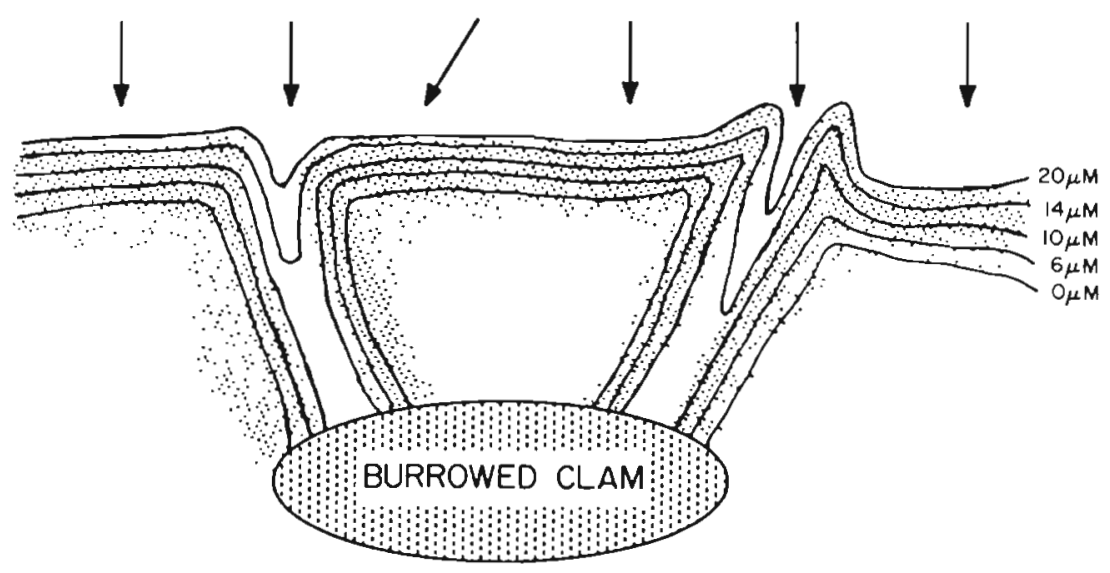

SUB-OXIC ZONE
Fig. 7. Lucinoma aequizonata. Vertical section through a clam burrow, showing both mucus-lined inhalant and exhalant siphon. The oxygen isopleths of the sediment and siphons were constructed from 6 microprofiles (arrows) traversing the burrow. Scale bar $=2 \mathrm{~cm}$
The siphon walls were often orange, probably due to iron oxide accumulation.

Analyses of the artificial habitats have shown that the clam, although positioned near the sediment surface, uses its vermiform foot to extend and penetrate repeatedly up to 3 times its body length into the sediment. The foot often remained fully extended down in the sediment for prolonged periods of time. The clams were observed to dig 4 to 5 tunnels below the burrow each week. These tunnels would often remain for 10 to $15 \mathrm{~d}$.

\section{DISCUSSION}

\section{Habitat characterization}

The profiles of pore water constituents that are either produced or consumed during organic carbon oxidation can be used to identify the redox conditions in the sediments (Froelich et al. 1979). Such profiles enable us to interpret the position and mobility of certain reduced compounds in the sediment. The shapes of the profiles are dependent on oxygen conditions, detrital carbon input, and the influence of bioturbation. In most organic-rich sediments, the complete redox sequence is compressed into the upper few centimeters unless bioturbation irrigates the mud enough to extend the profiles deeper.

The depth and characteristics of the metal profiles in the pore waters from the $500 \mathrm{~m}$ contour of the Santa Barbara Basin indicate substantial bioturbation. However, the extent of these redox sequences does not appear to include significant sulfate reduction, as indicated by lack of sulfide and a diminishing sulfate profile. Sediments such as these that are devoid of oxygen and have a high organic load would normally support extensive sulfate reduction with sulfide accumulation.
An increase in ammonia concentration, as seen in the lower portions of the core, is a result of denitrification and would normally identify the region of sulfate reduction. In addition, the presence of metal-bound sulfides (acid-volatile sulfides) verifies that some sulfate reduction does occur in the sediment. It is conceivable that slight sulfate reduction is present yet the products are below our detection limits $(0.5 \mu M)$ and that infaunal mixing of the sediments, as suggested by the lack of visible varving, could irrigate the sediment enough to replenish any reduced sulfate and oxidize any sulfide that has been produced. The lack of an established sulfide boundary, as would normally occur in similar sediments, may also be attributed to the rapid titration of sulfide by high concentration of dissolved iron available throughout the upper portions of the sections. These metal sulfides may be moved up in the sediment by the infauna where they are reoxidized.

Although the sediment lacks oxygen, the presence of sulfate not detectably different from the overlying seawater signifies the absence of intense anoxia. Froelich et al. (1979) described a similar environment as suboxic rather than anoxic because of the incomplete nature of the redox sequence. We are, therefore, more apt to define the habitat of Lucinoma aequizonata as sub-oxic and postulate that the unique geochemistry of this restricted habitat is maintained through the extensive mixing by the infaunal populations. This mixing is important because it limits the possible accumulation of sulfide.

The lack of a distinct source of dissolved sulfide in the sediment is a paradox, because the chemosynthetic bacterial endosymbionts in the gills of the clams reportedly rely on reduced sulfur compounds (Vetter 1985 , Dando et al. 1986) and would then presumably require a source of reduced sulfur (e.g. sulfide, thiosulfate, polythionate, sulfite, or elemental sulfur). In addition, 
the presence of elemental sulfur accumulating in the gills of Lucinoma aequizonata suggests that the endosymbionts are receiving adequate supplies of reduced sulfur compounds (Vetter 1985). During periods when reduced sulfur compounds are abundant, certain sulfur-oxidizing bacteria store elemental sulfur within the periplasmic space as a stable intermediate oxidation product (Schedel \& Trüper 1980, Lawrey et al. 1981, Strohl et al. 1981).

Dando et al. $(1985,1986)$ have identified several symbiont-containing bivalves capable of oxidizing reduced sulfur compounds that also reside in sediments low in sulfide. They suggest that the low concentrations of reduced sulfur immediately available in the sediment is insufficient to meet the needs of the symbionts (Dando et ai. 1985), and have proposed 2 mechanisms that might augment the supply. Reduced sulfur compounds could be obtained (1) from partially oxidized bound metal sulfides (iron sulfide) available through the walls of the inhalant siphon or (2) from biogenic remineralization of accumulated pseudofeces. Both mechanisms appear unlikely in the case of Lucinoma aequizonata as metal sulfides in the vicinity of the short siphons were below detection limits and no sulfide accumulation occurred in the sediments immediately associated with the clam.

The elevated sulfide and thiosulfate concentrations in the blood of naturally occurring Lucinoma aequizonata suggest that they are experiencing much higher levels than have been detected routinely at any specific depth in the cores (Table 1). Although sensitive HPLC techniques could not detect any distinct sulfide boundaries within the cores, small ( 1 to $2 \mathrm{~cm}$ diameter) isolated pockets of black sulfidic mud were found randomly dispersed in the sediment. These pockets, presumably caused by the deaths of infaunal organisms, often had sulfide levels 2 orders of magnitude higher than the surrounding sediment and might suggest an alternative strategy for the clams to obtain reduced sulfur. The frequency and longevity of these patches are unknown. However, they could provide a peripheral source of sulfide sufficient for the symbiosis if they were accessible to the clams. A characteristic of several lucinid species is their capacity to establish an extensive network of tunnels deep in the sediment (Stanley 1970, Dando \& Southward 1986). These tunnels are produced by the foot and often exceed $20 \mathrm{~cm}$ in depth. In the artificial habitat experiments specimens of $L$. aequizonata established and maintained an average of 4 to 5 tunnels each week. It is conceivable that the repetitive probing by the clam would be an efficient mechanism to locate these isolated sources of sulfide. In addition, the blood sulfide concentrations of $L$ aequizonata reflect the lower range of sulfide concentration detected in these isolated pockets of sulfide production. These data provide indirect evidence that transport of reduced sulfur compounds from these isolated patches to the clam occurs.

\section{Blood thiols}

Lucinoma aequizonata maintains a position in the sediment to acquire poorly oxygenated overlying water and reduced sulfur compounds from deeper in the mud, for its symbionts (Fig. 7). Sulfide, the most reduced form of sulfur, is a highly toxic molecule that poisons the cytochrome $c$ oxidase system and inhibits aerobic respiration at concentrations in the low micromolar range (National Research Council 1979). Adaptations to avoid sulfide toxicity have been discovered in several marine invertebrates residing in sulfide-rich habitats including the blood-binding protein found in the hydrothermal vent tube worm Riftia pachyptila (Arp \& Childress 1983), and the highly specialized hepatopancreas of the vent crab Bythograea thermydron (Vetter et al. 1987). The levels of reduced sulfur compounds in the blood of $L$. aequizonata indicate how these clams might extract sulfide from the sediment and resist its possible toxic effects. Sulfide concentrations in the blood and mantle water of naturally occurring clams are similar regardless of gill color. However, blood thiosulfate was considerably elevated over blood sulfide only in clams with stores of elemental sulfur. These reduced sulfur concentrations were considerably higher than those found in the sediment. Clams held at elevated external sulfide levels showed an increase of the blood sulfide concentration to match the external concentration. In addition, during prolonged incubations, blood thiosulfate concentrations increased by almost 2 orders of magnitude. When yellow-gilled clams were held free of sulfide, thiosulfate in the blood was rapidly depleted to match levels normal to black-gilled animals.

These observations suggest that the host extracts sulfide from the sediment and partially oxidizes it to thiosulfate, a slightly less energy-rich form of reduced sulfur. As thiosulfate, the charged reduced sulfur is non-toxic, somewhat less diffusible than sulfide (Beerman 1924), and can be concentrated in the blood. It is possible that this oxidation process may occur at the extremities of an extended foot. The enzyme sulfide oxidase, which would be responsible for this initial oxidation process, has higher activity in the foot than in the mantle tissue of Lucinoma aequizonata (J. O'Brien pers. comm.). Thiosulfate and possibly low levels of sulfide in the blood could then be supplied to meet the energetic needs of the symbiotic bacteria. Thiosulfate stimulates $\mathrm{CO}_{2}$ fixation in the sulfur symbiont-containing sewage clam Solemya reidi (Anderson et al. 1987) 
and the hydrothermal vent mussel Bathymodiolus thermophilus (Belkin et al. 1986). It is conceivable that in our incubation experiments, where all tissues of the clam were bathed in elevated concentrations of sulfide, the oxidizing capacity of the foot could not cope with the sulfide available resulting in an increase of blood sulfide concentrations.

The use of a sulfide oxidation mechanism which is peripheral to the host appears to be an efficient technique to modulate internal sulfide concentrations. As mentioned earlier, when external sulfide levels were increased in the laboratory the host continued to oxidize the sulfide partially to thiosulfate as indicated by the extremely high concentrations of thiosulfate in the blood. This resulted in a massive accumulation of elemental sulfur in the gills. In addition, recent gill tissue analyses using a modified Limulus lysate assay (Watson et al. 1977) demonstrated that an increase in elemental sulfur is accompanied by an increase in bacterial biomass (Cary unpubl.). Although these conditions may appear optimal for the bacteria, clams incubated in sulfide concentrations greater than $10 \mu \mathrm{M}$ showed both decreasing growth rates and increased mortality. It appears that these higher concentrations of sulfide bathing the entire clam were beyond the oxidizing capabilities of the host to maintain sulfide at nontoxic levels in the blood, and eventually the blood sulfide levels increase resulting in metabolic stress in the host. Maintenance of the source of sulfide coupled with a process of partial oxidation is an effective technique to maintain homeostasis. In addition, it has been suggested for Solemya reidi, a clam inhabiting sulfiderich environments, that the oxidation of sulfide by the host might be coupled to oxidative phosphorylation resulting in ATP synthesis (Powell \& Somero 1986). This, however, has not been examined in Lucinoma aequizonata.

The present study is the first attempt to determine fine-scale growth rates of an infaunal bivalve. The growth rates of Lucinoma aequizonata are extremely slow when compared to Mytilus edulis fed natural phytoplankton (Stromgren \& Cary 1984) or to mussels that contain methylotrophic endosymbiotic bacteria, fed only methane (Cary et al. 1988). However, the conditions under which the clams in this study were held were far from optimal and the growth rates should not be considered to represent in situ rates. These growth measurements can only be used as an indicator of present condition for comparison between the various environmental treatments.

Schedel \& Trüper (1980) demonstrated that the facultative anaerobe Thiobacillus denitrificans, which derives its energy from the oxidation of reduced sulfur compounds, grows anaerobically only with thiosulfate as the electron donor and nitrate as the terminal elec- tron acceptor. When thiosulfate is in excess, a conspicuous amount of elemental sulfur is transiently accumulated intracellularly in a highly reactive state that is immediately available as an energy source when thiosulfate levels decrease. Thiosulfate is cleaved by rhodanese into 2 sulfur moieties with oxidation states of elemental sulfur and sulfite. The elemental sulfur is anaerobically oxidized to sulfite in a reaction catalyzed by a siroheme-containing enzyme with the required oxygen derived from water molecules.

Several observations infer a relationship between the energy-acquiring strategies used by Thiobacillus denitrificans and the symbionts of Lucinoma aequizonata. First, when the symbionts of $L$. aequizonata experienced high blood thiosulfate concentrations there was a corresponding increase in the levels of intracellular elemental sulfur in the symbionts. This sulfur was utilized when the clams were held free of sulfide and blood thiosulfate concentrations decreased. Secondly, the potential for nitrate reduction has been reported in $L$. aequizonata by the presence of nitrate reductase (J. Stein pers. comm.), however, this assay is not specific to an assimilatory enzyme but could be measuring the enzymes used for dissimilatory reduction of nitrate by the electrons generated through the anaerobic oxidation of thiosulfate. Thirdly, the activity of rhodanese in $L$. aequizonata is the highest reported for any sulfur symbioses (Felbeck et al. 1981) and could identify the importance of thiosulfate in the metabolic strategy of the symbionts. Fourthly, $\mathrm{CO}_{2}$ fixation rates in bacteria isolated from the gills of $L$. aequizonata increased dramatically when held under low oxygen conditions (J. Pino pers. comm.).

If Lucinoma aequizonata does follow a similar metabolic strategy to Thiobacillus denitrificans the clam must maintain a low oxygen environment in the vicinity of the bacteria in order to avoid the poisoning of nitrate reductase, together with an ample supply of nitrate. The very low ambient oxygen concentration at the depth of occurrence in the Santa Barbara Basin and in the burrow may in itself be sufficient. In addition, a soluble protein characterized with a typical heme Soret absorbtion band has been detected in the gill tissue (Cary unpubl.). Other symbiont-containing bivalves from low sulfide environments contain similar heme proteins having extremely high oxygen binding affinities (Read 1962, Fisher \& Hand 1984, Dando et al. 1985). The function of these heme proteins might be to protect the symbionts from excess oxygen that could interfere with autotrophic processes especially during periods when the basin flushes and oxygen concentrations increase. The requirements of nitrate should be adequately met by accessing the high concentrations $(40 \mu M)$ in the water overlying the sediment. $T$. denitrificans grows anaerobically when nitrate is limiting 
(Justin \& Kelly 1978a) relying on an oxygen-sensitive sulfite-dependent nitrate reductase reported to have a high affinity for sulfite (Michaelis constant $K_{\mathrm{m}}$ of 1.5 $\mu M$, Sawhney \& Nicholas 1977, Justin \& Kelly 1978b).

To summarize, it is conceivable that during periods when sulfide is not available to the clam, the endosymbiotic bacteria will utilize the thiosulfate pool in the blood and, once that is depleted, will draw on their own elemental sulfur stores. It is presumed that during this time the transport or production of bacterial translocation product declines resulting in decreased growth rates of the host. After a prolonged period of sulfur starvation the gills blacken and atrophy due to the reduction of sulfur stores and the endosymbiont population, as was similarly reported by Southward (1986) With the symbiont population depleted, the host must subsist on stored reserves such as glycogen. In the laboratory we maintained several Lucinoma aequizonata alive for up to 1 yr without a source of reduced sulfur. The randomness and transitory nature of sulfide in this habitat may imply long periods between available sulfide and might account for the extreme individual variability measured in blood sulfide, thiosulfate and gill elemental sulfur content.

\section{Alternative sources of reduced carbon}

Because of the unpredictable availability of reduced sulfur in this habitat, it is important to evaluate other possible sources of reduced carbon. Stable carbon isotopes are particularly useful in verifying the existence and assessing the nutritional contribution of prokaryotic endosymbionts in marine invertebrates (Rau 1981, Southward et al. 1981, Paull et al. 1985, Brooks et al. 1987). The ${ }^{13} \mathrm{C} /{ }^{12} \mathrm{C}$ ratios for Lucinoma aequizonata fall within the range reported for other bivalves that contain sulfur-oxidizing chemolithoautotrophic endosymbiotic bacteria (Fig. 5). L. aequizonata are considerably depleted in ${ }^{13} \mathrm{C}$ in comparison to heterotrophic representatives from the same habitat whose isotope values reflect dietary carbon derived ultimately from marine phytoplankton (Gearing et al. 1984). The carbon isotope values closely reflect $\mathrm{CO}_{2}$ fixed by prokaryotic carboxylase (Degens 1969, Ruby et al. 1987) which confirms the importance of the endosymbionts as a source of reduced carbon to the host.

Previous isotope studies have qualitatively assessed the contribution of the bacteria by directly comparing symbiont and non-symbiont containing tissues; unfortunately in these studies most of the biomass in the symbiont containing tissue belonged to the host. More recently, Conway et al. (1988) partially purified the endosymbiotic bacteria from the gills of Solemya velum in order to reduce the possible isotopic influence of contaminating host tissue. This permitted a more quantitative assessment of the host-symbiont nutritional relationship. The carbon isotope values of the bacterial fraction and host tissue were similar, and a 2-source mixing model that incorporated isotopic values of filterfeeding bivalves from the same habitat as $S$. velum revealed that $S$. velum obtains almost all $(98 \%)$ of its reduced carbon from its endosymbiotic bacteria.

In the present study, we were able to obtain bacterial preparations from the gills of Lucinoma aequizonata that were clear of host tissue. The purified bacteria had the lightest $\delta^{13} \mathrm{C}$ values $(-34 \%)$ reported for this type of symbiosis, and were significantly lighter than those of host tissue $(-29 \%)$. The tissues of an animal are usually slightly enriched ( 1 to $2 \%$ ) in ${ }^{13} \mathrm{C}$ in comparison to that of their food (DeNiro \& Epstein 1978). The isotopic distance between $L$. aequizonata and its symbiont was considerably greater ( $5 \%$ ) than that reported for Solemya velum (Conway et al. 1988) and reflects the influence of an additional carbon source(s) with heavier carbon isotope characteristics. If we assume that the carbon isotope ratios of the control bivalve Cyclocardia ventricosa reflect a plant-based food source, and the $\delta{ }^{13} \mathrm{C}$ values measured in the purified bacteria is representative of the endosymbionts, then it is possible to estimate the contribution of each of the 2 food sources to the carbon budget of $L$. aequizonata employing the 2-source mixing model of Conway et al. (1988). From this model we estimate that $L$. aequizonata is dependent on its symbionts for $75 \%$ of its reduced crabon. Therefore, it is critical to establish the importance of possible alternative sources of carbon that might contribute to the remaining $25 \%$.

Most lucinids have a simplified but functional gut adapted for conditions where the food supply is scarce (Allen 1958). Although the filtering and sorting mechanisms of the lucinids are relatively inefficient, the guts of several species contain large particles including diatoms (Dando et al. 1986). The stomachs of 4 specimens of Lucinoma aequizonata collected directly out of the sediment were examined and all were found to be empty. Although this is not conclusive, it seems that filter-feeding is not an important source of nutrition to these clams.

Another possible source of reduced carbon could be dissolved free amino acids (DFAA), which were found in high concentrations in the pore waters. Since DFAA in marine sediments are generally enriched in ${ }^{13} \mathrm{C}$ relative to most chemoautotrophically derived carbon (Degens 1969) they could contribute to the heavy isotopic values of the host tissue discussed above. The DFAA concentrations can be compared with those found in more highly productive estuarine and coastal upwelling areas (Henrichs \& Farrington 1979, Jørgensen et al. 1981, Henrichs et al. 1984). Concentrations of 
DFAA in these sediments are 1 to 2 orders of magnitude greater than the levels of DFAA that would be considered an important nutritional source of reduced carbon to filter feeding bivalves (Wright 1982). However, DFAA that are held within the sediment would generally be accessible only to infaunal species.

Certain sediment-dwelling pogonophorans, which also contain sulfur-oxidizing symbionts and live in lowsulfide habitats, are capable of accumulating significant amounts of the DFAA available in the sediment pore waters. It has been suggested that the nutritional demands for maintenance and growth of the pogonophoran Siboglinum fiordicum could be met solely on a diet of the DFAA available in the sediment or on $20 \%$ of the reduced carbon fixed by its symbionts (Southward \& Southward 1988). If the clams are extracting sulfide by probing deeper into the sediment, it is conceivable that at the same time significant amounts of DFAA may also be obtained, providing a continuous input of reduced carbon and amino nitrogen. The uptake rate of DFAA by Lucinoma aequizonata has not been investigated; however, such a nutritional supplement could be important, particularly during periods when sulfide is not available and presumably the translocation of bacterial carbon is greatly reduced.

\section{CONCLUSION}

Adults of Lucinoma aequizonata live in a sub-oxic habitat that is maintained by bioturbation. This infaunal mixing appears to restrict the accumulation of reduced sulfur compounds in the sediment. The clams obtain reduced sulfur for their resident endosymbionts from isolated pockets of sulfidic mud randomly dispersed in the sediment. It appears that by periodically tapping these peripheral sulfide supplies and by the partial oxidation of the sulfide to thiosulfate, the host can modulate the internal sulfide concentrations below toxic levels. Thiosulfate is non-toxic and can be concentrated in the blood where it is eventually utilized by the endosymbionts as an energy source without harm to the host. When external sulfide concentrations exceed a critical level, toxicity to the clam can be avoided by the reduction of pumping rates or increased host-mediated sulfide oxidation. This study confirms that (1) elemental sulfur is stored by the bacteria during periods when sulfide and thiosulfate are abundant, and (2) utilized when fluctuations in the redox state of the sediments limits the availability of reduced sulfur.

The stable carbon isotope ratio distance between the bacteria and host suggests that about $75 \%$ of the hosts reduced carbon originated from the endosymbionts. The presence of high concentrations of DOM trapped in the sediment pore waters could account for the heavier host carbon values. It appears that the clam maintains a motile habitat and is capable of tracking and accessing randomly dispersed sources of energy for its symbionts.

Acknowledgements. The authors are indebted to many individuals for their assistance during the course of these studies. We especially thank D. Manahan for his help and encouragement during the amino acid analyses, to A. Schimmelmann for his mastery in stable isotope analysis, and to C. E. Reimers and $\mathrm{J}$. Gieskes for many hours of discussion on the geochemistry of the Santa Barbara Basin. We also thank the laboratory of J. Childress, W. Wright, R. Mereweather, J. Bernard, T. Shaw, I. Brown, J. Pino, D. Distel, D. Wilmot, J. O'Brien and especially S. Wiley for many hours of assistance while at sea and in the laboratory. Funding for this research was provided by NSF OCE-8610512 to HF, OCE86-10513 to R.V and George Somero and OCE-8714996 to C. E. Reimers, partially from ONR N00014-87-0012 to R.V., and through a UCSD Biomedical Research Grant, a Sigma Xi Grants-in-Aid of Research and a Scripps Industrial Associates Grant to C.C.

\section{LITERATURE CITED}

Arp, A. J., Childress, J. J. (1983). Sulfide binding by the blood of the hydrothermal vent worm Riftia pachyptila. Science 219: $295-297$

Allen, J. A. (1958). On the basic form and adaptations to the habitat in the Lucinaceae (Eulamellibranchia). Phil. Trans. R. Soc. B. 241, 421-484

Anderson, A. E., Childress, J. J., Favuzzi, J. A. (1987). Net uptake of $\mathrm{CO}_{2}$ driven by sulfide and thiosulfate oxidation in the bacterial symbiont-containing clam Solemya reidi. J. exp. Biol. 133: 1-31

Belkin, S., Nelson, D. C., Jannasch, H. W. (1986). Symbiotic assimilation of $\mathrm{CO}_{2}$ in two hydrothermal vent animals, the mussel Bathymodiolus thermophilus and the tube worm Riftia pachyptila. Biol. Bull mar biol. Lab., Woods Hole 170: 110-121

Beerman, H. (1924). Some physiological actions of hydrogen sulfide. J. exp. Zool. 41:33-43

Bewer, P. G., Spencer, D. W (1971). Colormetric determination of manganese in anoxic waters. Limnol. Oceanogr. 16 : $107-112$

Broenkow, W. W., Cline, J. D. (1969). Colorimetric determination of dissolved oxygen at low concentrations. Limnol. Oceanogr. 14: 450-454

Brooks, J. M., Kennicutt, M. C., Fisher, C. R., Macko, S. A., Cole, K., Childress, J. J., Bidigare, R. R., Vetter, R. D (1987). Deep-sea hydrocarbon seep communities: evidence for energy and nutritional carbon sources. Science 238: 1138-1142

Cary, S. C., Fisher, C. R., Felbeck, H. (1988). Mussel growth supported by methane as sole carbon and energy source. Science 240: 78-80

Cavanaugh, C. M. (1983). Symbiotic chemoautotrophic bacteria in marine invertebrates from sulfide-rich habitats. Nature, Lond. 302: 58-61

Cline, J. D. (1969). Spectrophotometric determination of hydrogen sulfide in natural waters. Limnol. Oceanogr. 14 $454-458$

Conway, N., McDowell-Capuzzo, J., Fry, B. (1989). The role of endosymbiotic bacteria in the nutrition of Solemya velum: evidence from stable isotope analysis of endosymbionts and host. Limnol. Oceanogr 34: 249-255 
Dando, P. R., Southward, A. J. (1986). Chemoautotrophy in bivalve molluscs of the genus Thyasira. J. mar. biol. Ass. U. K. $66: 915-929$

Dando, P. R., Southward, A. J., Southward, E. C. (1986). Chemoautotrophic symbionts in the gills of the bivalve mollusc Lucinoma borealis and the sediment chemistry of its habitat. Proc. R. Soc. B. 227-227-247

Dando, P. R., Southward, A. J., Southward, E. C., Terwilliger, N. B., Terwilliger, R. C. (1985). Sulphur-oxidizing bacteria and haemoglobin in gills of the bivalve mollusc Myrtea spinifera. Mar Ecol. Prog. Ser 23: 85-98

Degens, E. I (1969). Biogeochemistry of stable carbon isotopes. In: Eglington, G., Murphy, M. T. G. (eds.) Organic geochemistry methods and results. Springer, Berlin. p. 304-329

DeNiro, E. T., Epstein, S. (1978). Influence of diet on the distribution of carbon isotopes in animals. Geochim. Cosmochim. Acta. 42: 495-506

Distel, D. L., Felbeck, H. (1988). Pathways of inorganic carbon fixation in the endosymbiont-bearing lucinid clam Lucinoma aequizonata. Part 1. Purification and characterization of the endosymbiont bacteria. J. exp. Zool. 247 : $1-10$

Fahey, R. C., Newton, G. R. (1987). Determination of lowmolecular weight thiols using monobromobimane fluorescent labeling and high-performance liquid chromatography. In: Jacoby, W. B., Griffith, O. W (eds.) Methods in enzymology, Vol. 143. Academic Press, New York, p. $85-95$

Felbeck, H. (1981). Chemoautotrophic potential of the hydrothermal vent tube worm, Riftia pachyptila Jones (Vestimentifera). Science 213: 336-338

Felbeck, H. (1983). Sulfide oxidation and carbon fixation by the gutless clam Solemya reidi: and animal bacteria symbiosis. J. comp. Physiol. 152: 3-11

Felbeck, H. (1985). $\mathrm{CO}_{2}$ fixation in the hydrothermal vent tube worm Riftia pachyptila (Jones). Physiol. Zool. 58: 272-281

Felbeck, H., Childress, J. J., Somero, G. N. (1981). CalvinBenson cycle and sulfide oxidation enzymes in animals from sulfide-rich habitats. Nature, Lond. 293: 291-293

Felbeck, H., Liebezeit, G., Dawson, R., Giere, O. (1983). CO fixation in tissues of marine oligochaetes (Phallodrilus leukodermatus and $P$. planus) containing symbiotic, chemoautotrophic bacteria. Mar Biol. 75: 187-191

Fisher, M. R., Hand, S. C. (1984). Chemoautotrophic symbionts in the bivalve Lucina floridana from seagrass beds. Biol. Bull. mar biol. Lab., Woods Hole 167: 4.45-459

Froelich, P. N., Klinkhammer, G. P., Bender, M. L., Luedtke, N. A., Heath, G. R., Cullen, D., Dauphin, P., Hammond, D., Hartman, B. (1979). Early oxidation of organic matter in pelagic sediments of the eastern equatorial Atlantic: suboxic diagenesis. Geochim. Cosmochim. Acta 43 . $1075-1090$

Fry, B., Sherr, E. B. (1984). ${ }^{13} \mathrm{C}$ measurements as indicators of carbon flow in marine and freshwater ecosystems. Contr mar. Sci. 27: 13-47

Geanng, J. N., Gearing, D. T., Rudnick, D. T., Requejo, A. G., Hutchins. M. J. (1984). Isotope variability of organic carbon in a phytoplankton-based temperate estuary. Geochim. Cosmochim. Acta. 48: 1089-1098

Gieskes, J. M., Peretsman, G. (1986). Water-chemistry procedures aboard Jiodes Resolution - some comments. Ocean Drilling Program, Texas A \& M University, Technical Note No. 5, p. $1-46$

Henrichs, S. M., Farrington., J. W. (1979). Amino acids in interstitial water of marine sediments. Nature, Lond. 279: $319-322$
Henrichs, S. M., Farrington, J. W., Lee, C. (1984). Peru upwelling region sediments near $15^{\circ} \mathrm{S}$. 2. Dissolved free and total hydrolyzable amino acids. Limnol. Oceanogr. 29 $20-34$

Hülsemann, J., Emery, K. O. (1961). Stratification in recent seciments of Santa Barbara Basin as controlled by organisms and the water character. J. Geol. 69:279-290

Jorgensen, N. O., Lindroth, P., Mopper, K. (1981). Extraction and distribution of free amino acids and ammonium in sediments and overlying sea waters from Limfjord, Denmark. Oceanologica Acta 4: 465-474

Justin, P., Kelly, D. P. (1978a). Growth kinetics of Thiobacillus denitrificans in anaerobic and aerobic chemostat culture J. gen. Microbiol. 107: 123-130

Justin, P., Kelly, D. P. (1978b). Metabolic changes in Thiobacillus denitrificans accompanying the transition from aerobic to anaerobic growth in continuous chemostat culture. J. gen. Microbiol. 107: 131-137

Keppler, D., Decker, K. (1983). Glycogen. In: Bergmeyer, H. U (ed.) Methods of enzymatic analysis, Vol. VI, Metabolites 1: Carbohydrates. Verlag Chemie, Weinheim, p. 11-17

Klug, M., Boston, P., Francois, R., Gyure, R., Javor, B., Tribble, G., Vairavamurthy, A. (1985). Sulfur reduction in sediments of marine and evaporite environments. In: The global sulfur cycle. Sagan, D. (ed.) NASA Technical Memorandum 87570, Washington, D.C., p. 128-156

Lawrey, N. H., Jani, V., Jensen, T. E. (1981). Identification of the sulfur inclusion body in Beggiatoa alba B18LD by energy-despersive X-ray microanalysis. Curr. Microbiol. 6 : $71-74$

Lindroth, P., Mopper, K. (1979). High performance liquid chromatography determination of subpicomole amounts of amino acids by precolumn fluorescence derivatization with o-phthaldialdehyde. Analyt. Chem. 51: 1667-1674

Manahan, D. T., Wright, S. H., Stephens, G. C. (1983). Simultaneous determination of net uptake of 16 amino acids by a marine bivalve. Am. J. Physiol. 244: 832-838

National Research Council (1979). Hydrogen sulfide. Committee on medical and biological effects of environmental pollutants, subcommittee on hydrogen sulfide; division of medical sciences, Assembly of Life Sciences. University Park Press, Baltimore

Northfelt, D. W., Deniro, M. J., Epstein, S. (1981). Hydrogen and carbon isotopic ratios of cellulose nitrate and saponifiable lipid fractions prepared from annual growth rings of a California Redwood. Geochim. Cosmochim. Acta. 45 $1895-1898$

Paull, C. K., Hecker, B., Commeau, R., Freeman-Lynde, R. P., Newmann, C., Corso, W. P., Golubic, S., Hook, J. E., Sikes, E. Curray, J. (1984). Biological communities at the Florida escarpment resemble hydrothermal vent taxa. Science 226: $965-967$

Rau, G. (1981). Hydrothermal vent clam and tube worm ${ }^{13} \mathrm{C} /$ ${ }^{12} \mathrm{C}$ : further evidence of non-photosynthetic food sources. Science 213: 338-340

Rau, G. H. $(1985) .{ }^{13} \mathrm{C} /{ }^{12} \mathrm{C}$ and ${ }^{15} \mathrm{~N} /{ }^{14} \mathrm{~N}$ in hydrothermal vent organisms: Ecological and biogeochemical implications. Bull biol. Soc. Wash. 6: 243-24.7

Rau, G. H., Hedges, J. I. (1979). Carbon-13 depletion in a hydrothermal vent mussel: suggestion of a chemosynthetic food source. Science 203: 648-649

Rau, G. H., Mearns, A. J., Young, D. R., Olson, R. J., Schafer H. A., Kaplan, I. R. (1983). Animal ${ }^{13} \mathrm{C} /{ }^{12} \mathrm{C}$ correlates with trophic level in pelagic food webs. Ecology 64 : 1314-1318

Read, K. R. H. (1962). The hemoglobin of the bivalve mollusc Phacoides pectinatus (Gmelin). Comp. Biochem. Physiol. 1.5: $137-158$ 
Reid, R. G. B. (1980). Aspects of the biology of a gutless species of Solemya (Bivalvia: Protobranchia). Can. J. Zool. 58. 386-393

Revsbech, N. P., Jørgensen, B. B., Blackburn, T H. (1980), Oxygen in the seabottom measured with microelectrode. Science 207: 1355-1356

Revsbech, N. P., Ward, D. M. (1983). Oxygen microelectrode that is insensitive to medium chemical composition: use in an acid microbial mat dominated by Cyanidium caldarium. Appl. environ. Microbiol. 45: 755-759

Ruby, E. G., Jannasch, H. W., Deuser, W. G. (1987). Fractionation of stable carbon isotopes during chemoautotrophic growth of sulfur-oxidizing bacteria. Appl. environ. Microbiol. 53: 1940-1943

Sawhney, V., Nicholas, D. J. D. (1977). Sulfite- and NADHdependent nitrate reductase from Thiobacillus denitrificans. J. gen. Microbiol. 100: 49-58

Schedel, M., Trüper, H. G. (1980). Anaerobic oxidation of thiosulfate and elemental sulfur in Thiobacillus denitrificans. Arch. Microbiol. 124. 205-210

Schweimanns, M., Felbeck, H. (1985). Significance of the occurrence of chemoautotrophic bacterial endosymbionts in lucinid clams from Bermuda. Mar. Ecol. Prog. Ser. 24: $113-120$

Sholkovitz, E. R., Gieskes, J. M. (1971). A physical chemical study of the flushing of the Santa Barbara Basin. Limnol. Oceanogr 16: 479-489

Solorzano, L. (1969). Determination of ammonia in natural waters by phenol-hypochlorite method. Limnol. Oceanogr. 14: 799-801

Soutar, A., Crill, P. A. (1977). Sedimentation and climatic patterns in the Santa Barbara Basin during the $19^{\text {th }}$ and $20^{\text {th }}$ centuries. Bull. geol. Soc. Am. 88: 1161-1172

Southward, A. J., Southward, E. C. (1988). Pogonophora. In: Pandian, T J., Vernberg, F. J. (eds.) Animal energetics, Vol. 2. Academic Press, London, p. 201-228

Southward, A. J., Southward, E. C., Dando, P. R., Rau, G. H., Felbeck, H., Flügel, H. (1981). Bacterial symbionts and low ${ }^{1.3} \mathrm{C} /{ }^{12} \mathrm{C}$ ratios in tissues of Pogonophora indicate unusual nutrition and metabolism. Nature, Lond. 293: 616-620

Southward, E. C. (1986). Gill symbionts in thyasirids and other bivalve molluscs. J. mar. biol. Ass. U. K. 66: 889-914

Spiro, B., Greenwood, P. B., Southward, A. J., Dando, P. R. $(1986) .{ }^{13} \mathrm{C} /{ }^{12} \mathrm{C}$ ratios in marine invertebrates from reducing sediments: confirmation of nutritional importance of

This article was presented by Professor N. D. Holland, La Jolla, California, USA chemoautotrophic endosymbiotic bacteria. Mar Ecol. Prog. Ser. 28: 233-240

Stanley, S. M. (1970). Relation of shell to life habitats of the Bivalvia (Mollusca). Mem. geol. Soc. Am. 125: 1-293

Stookey, L. L. (1970). Ferrozine - a new spectrophotometric reagent for iron. Analyt. Chem. 42: 779-784

Strickland, J. D., Parsons, $\Upsilon \Upsilon$ (1972). A practical handbook of seawater analysis, 2nd edn. Bull. Fish. Res. Bd Can. 167: $1-311$

Strohl, W. R. I., Geffers, I., Larkin, J. M. (1981). Structure of the sulfur inclusion envelopes from four Beggiatoas. Curr Microbiol. 6: 75-79

Stromgren, T., Cary, S. C. (1984). Growth in length of Mytilus edulis L. fed on different algal diets. J. exp. mar. Biol. Ecol. 76: 23-34

Stump, R. K., Frazer, J. W. (1973). Simultaneous determination of carbon, hydrogen and nitrogen in organic compounds. Nucl. Sci. Abstr. 28: 746-746

Tabatabai, M. A. (1974). A rapid method for determination of sulfate in water samples. Environ. Lett. $7: 237-243$

Vetter, R. D. (1985). Elemental sulfur in the gills of the three species of clams containing chemoautotrophic symbiotic bacteria: a possible energy storage compound. Mar. Biol. 88: $33-42$

Vetter, R. D., Hodson, R. E. (1982). Use of adenylate concentrations and adenylate energy charge as indicators of hypoxia stress in estuarine fish. Can. J. Fish. Aquat. Sci. 39: 535-541

Vetter, R. D., Matrai, P. A., Javor, B., OBrien, J. (1989). Reduced sulfur compounds in the marine environment: analysis by HPLC. In: Saltzman, E. S., Cooper, W. F. (eds.) Biogenic sulfur in the environment. Am. Chem. Soc. Symp. Ser., ACS Press, Washington, D. C. 393: 243-261

Vetter, R. D., Wells, M. E., Kurtsman, A. L., Somero, G. N. (1987). Sulfide detoxification by the hydrothermal vent crab Bythogrea thermydron and other decapod crustaceans. Physiol. Zool. 60: 121-137

Watson, W. W., Novititsky, H. Q., Quimby, H. L., Valois, F. W. (1977). Determination of bacterial number and biomass in the marine environment. Appl, environ. Microbiol. 33: 940-946

Wright, S. H. (1982). A nutritional role for amino acid transport in filter-feeding marine invertebrates. Am. Zool. 22: $621-634$

Manuscript first received: December 13, 1988

Revised version accepted: April 11, 1989 